\title{
Effects of a transplantable insulinoma upon regulatory peptide concentrations in the gastrointestinal tract of the rat
}

\author{
J. M.Conlon ${ }^{1}$, C.F. Deacon ${ }^{1}$, C. J. Bailey ${ }^{2}$ and P. R. Flatt ${ }^{3}$ \\ ${ }^{1}$ Clinical Research Group for Gastrointestinal Endocrinology of the Max-Planck-Gesellschaft at the University of Göttingen, Göttingen, FRG, \\ ${ }^{2}$ Department of Molecular Sciences, University of Aston in Birmingham, and \\ ${ }^{3}$ Department of Biochemistry, University of Surrey, Guildford, UK
}

Summary. The rapid growth $(0.8 \pm 0.3 \mathrm{~g} /$ day $)$ of a transplantable insulinoma, which also contained substance $P(2.9 \pm$ $2.3 \mathrm{pmol} / \mathrm{g})$ and gastrin-releasing peptide $(3.2 \pm 2.1 \mathrm{pmol} / \mathrm{g})$, resulted in the development of hyperphagia, hyperinsulinaemia and hypoglycaemia in rats $(n=8)$. After a 14-day growth period, the insulinoma-bearing rats showed an increase $(49 \% ; p<0.01)$ in the weight of the small intestine but no significant change in stomach weight compared with control animals. The content (pmol/organ) of somatostatin, substance $P$, neurokinin $A$ and vasoactive intestinal peptide in the stomachs of the tumour rats was unchanged. A depletion in the content $(53 \% p<0.01)$ and concentration $(57 \% ; p<0.01)$ of gastrin-releasing peptide, however, suggested either hypersecretion, possibly mediated through hypoglycaemia-induced vagal stimulation, or inhibition of synthesis. The concentra- tion and content of glucagon-like immunoreactivity (enteroglucagon) in the small intestine of the insulinoma rats in creased markedly $(47 \% ; p<0.01$ and $120 \% ; p<0.01)$. This increase is consistent with a proposed role of this peptide as a factor trophic to the intestinal mucosa. No significant changes in the concentrations of somatostatin, substance $P$, neurokinin $A$, vasoactive intestinal peptide and gastrin-releasing peptide in the small intestine were observed. However, the increase in gut weight resulted in a greater content of vasoactive intestinal peptide $(40 \% ; p<0.01)$ and substance $\mathrm{P}(37 \% ; p<$ $0.05)$ in the insulinoma rats.

Key words: Insulinoma, substance $P$, neurokinin A, vasoactive intestinal polypeptide, somatostatin, gastrin-releasing peptide, enteroglucagon.
A radiation-induced transplantable insulinoma, developed in NEDH (New England Deaconess Hospital) rats by Chick and coworkers [1], has been used to study the dynamics of insulin release in vivo $[2,3]$ and in vitro [4], the biosynthesis and compartmental storage of insulin [5] and the degradation of insulin [6]. The tumour has been used as a source of insulin secretory granules [7] and a means to raise monoclonal antibodies to islet cell membrane antigens [8]. This model offers the advantage over other animal insulinoma models, such as induction by streptozotocin-nicotinamide administration [9], in that the tumour develops very rapidly and contains a high content of insulin. The insulinoma-bearing rats become hyperphagic, hyperinsulinaemic and hypoglycaemic, leading to fatal neuroglycopaenic coma by $2-3$ weeks $[2,10]$. It has been shown [10] that adaptation of the pancreas to the growth of the transplanted insulinoma results in a severe depletion of endogeneous insulin and pancreatic polypeptide. Adaptation of the gastrointestinal tract has previously been studied in streptozotocin-diabetic rats [11] displaying hyperphagia, hypoinsulinemia and hyperglycaemia, and in hy- perphagic rats with pancreatic acinar atrophy [12] but normal insulin and glucose concentrations. The aim of this investigation was to study changes in the concentrations and total content of regulatory peptides somatostatin, vasoactive intestinal peptide (VIP), substance $P$, neurokinin A, gastrin-releasing peptide (GRP) and glucagon-like immunoreactivity (GLI or enteroglucagon) occurring in the stomach and small intestine during rapid growth of the insulinoma over a period of 14 days.

\section{Materials and methods}

Fragments of insulinoma tissue (approximately $0.1 \mathrm{~g}$ ) from a single donor rat were implanted subcutaneously into the subscapular region of 21-week-old male inbred NEDH rats (New England Deaconess Hospital, Boston, MA, USA) as previously described [2, 10]. Eight male rats of the same age and strain were used as controls. All animals had free access to a standard laboratory diet (Spratts laboratory diet 1, Lillico Ltd, Reigate, UK), and water and food intake was regularly monitored. After 14 days the insulinoma-bearing rats exhibited hyperphagia and signs of severe hypoglycaemia. The experiment was then terminated and all animals were killed by cervical dislocation. The stomachs of both groups contained food at the time of death. Tumour 
Table 1. Effects of a transplantable insulinoma on food intake and plasma concentrations of glucose and insulin in rats

\begin{tabular}{lcc}
\hline & $\begin{array}{l}\text { Insulinoma } \\
(n=8)\end{array}$ & $\begin{array}{l}\text { Control } \\
(n=8)\end{array}$ \\
\hline Food intake $(\mathrm{g} / 24 \mathrm{~h})$ & $26.6 \pm 1.8^{\mathrm{a}}$ & $11.0 \pm 2.7$ \\
Plasma glucose $(\mathrm{mmol} / \mathrm{l})$ & $0.9 \pm 0.4^{\mathrm{a}}$ & $7.1 \pm 0.5$ \\
Plasma insulin $(\mathrm{nmol} / \mathrm{l})$ & $3.4 \pm 0.6^{\mathrm{a}}$ & $0.43 \pm 0.02$ \\
\hline
\end{tabular}

Results are expressed as mean \pm SD. ${ }^{a} p<0.01$ versus control. Food intake was measured in the 24 -h period immediately before killing

Table 2. Effects of a transplantable insulinoma upon the weight of the digestive organs in rats

\begin{tabular}{lcc}
\hline & \multicolumn{2}{l}{ Weight $(\mathrm{g})$} \\
\cline { 2 - 3 } & $\begin{array}{l}\text { Insulinoma } \\
(n=8)\end{array}$ & $\begin{array}{l}\text { Control } \\
(n=8)\end{array}$ \\
\hline Body weight & $367 \pm 20$ & $370 \pm 28$ \\
Tumour & $11.4 \pm 4.3$ & - \\
Stomach & $1.4 \pm 0.1$ & $1.3 \pm 0.1$ \\
Small intestine & $9.2 \pm 0.6^{\mathrm{a}}$ & $6.2 \pm 0.8$ \\
\hline
\end{tabular}

Results expressed as mean \pm SD. ${ }^{a} p<0.01$ versus control

Table 3. Concentrations of regulatory peptides in extracts of a transplantable insulinoma

\begin{tabular}{lccccc}
\hline & \multicolumn{2}{l}{$\begin{array}{l}\text { Concentration } \\
(\mathrm{pmol} / \mathrm{g})\end{array}$} & \multicolumn{3}{l}{$\begin{array}{l}\text { Range } \\
(\mathrm{pmol} / \mathrm{g})\end{array}$} \\
\hline Insulin & $3260 \quad \pm 2260$ & \multicolumn{2}{c}{1080} & -7650 \\
Glucagon & $1.89 \pm$ & 2.36 & $0.59-$ & 7.64 \\
Somatostatin & $0.53 \pm$ & 0.37 & $0.17-$ & 1.32 \\
Substance P & $2.90 \pm$ & 2.31 & $0.84-$ & 6.78 \\
Neurokinin A & $0.52 \pm$ & 0.62 & $0.10-$ & 1.95 \\
$\begin{array}{l}\text { Vasoactive intestinal } \\
\text { peptide }\end{array}$ & $0.14 \pm$ & 0.11 & $0.03-$ & 0.31 \\
$\quad \begin{array}{l}\text { Gastrin-releasing } \\
\text { peptide }\end{array}$ & $3.15 \pm$ & 2.09 & $1.14-$ & 5.83 \\
\hline
\end{tabular}

Results expressed as mean $\pm \operatorname{SD}(n=8)$

tissue, the entire stomach and the small intestine were removed, washed with ice-cold isotonic saline and immediately frozen on dry ice. The tissues were weighed and stored at $-70^{\circ} \mathrm{C}$ until time of extraction. A blood sample was obtained by cardiac puncture at the time of death. Plasma glucose was determined by the glucose oxidase procedure.

\section{Tissue extraction}

Tumour tissue was extracted by the method of Kenny [13] using acidified ethanol. Solvent was removed under reduced pressure at $30^{\circ} \mathrm{C}$ and the residue redissolved in radioimmunoassay buffer $(0.05 \mathrm{~mol} / 1$ sodium phosphate, $\mathrm{pH} 7.4$ containing $0.14 \mathrm{~mol} / 1$ sodium chloride). Gastrointestinal tissues were extracted by the boiling acetic acid method previously described [11]. The extracts were assayed without lyophilization, but at a sufficient dilution that interference by the solvent in the radioimmunoassays was undetectable.

\section{Radioimmunoassays}

Insulin-like immunoreactivity (IRI) was measured using rat insulin standards and an antiserum raised against porcine insulin [14]. Somatostatin-like immunoreactivity (SLI), VIP-like immunoreactivity (VIPLI) and substance P-like immunoreactivity (SPLI) were measured as previously described [11]. Neurokinin A-like immunoreactivity (NKA-LI) was measured using an antiserum directed against the Cterminal region of neurokinin A that shows $0.4 \%$ cross-reactivity with substance P [15]. GLI was measured with an antiserum directed against the N-terminal to central region of glucagon (probably residues 10-15). The specificity of this antiserum has been described [16]; measurements made with antisera of this specificity are referred to as N-GLI determinations. GLI was also measured with the well-characterized C-terminally directed (residues 24-29) Unger antiserum $30 \mathrm{~K}$. These measurements are referred to as C-GLI. The difference between the N-GLI and C-GLI in the gut is frequently referred to as enteroglucagon.

Gastrin-releasing peptide was measured using an antiserum raised in sheep against the C-terminal region (residues 14-27) of porcine GRP supplied by Guildhay Antisera, Guildford, UK. Antiserum (final dilution 1:5000) $(100 \mu \mathrm{l})$ was incubated with approximately $10,000 \mathrm{cpm}\left(3-{ }^{125} \mathrm{I}\right]$ iodotyrosyl ${ }^{15}$ )-gastrin releasing peptide (specific activity $2000 \mathrm{Ci} / \mathrm{mmol}$; Amersham International PLC, Amersham, UK) and sample or standard $(100 \mu \mathrm{l})$ in $0.05 \mathrm{~mol} / 1$ sodium phosphate buffer, $\mathrm{pH} 7.4$, containing $0.14 \mathrm{~mol} / 1$ sodium chloride (final volume $500 \mu \mathrm{l})$. After $72 \mathrm{~h}$, antibody-bound radioactivity was precipitated by addition of polyethylene-glycol 6000 (final concentration $12 \%$ wt/ vol). The mid-range $\left(\mathrm{IC}_{50}\right)$ of the assay was $245 \mathrm{fmol} / \mathrm{ml}$ and the minimum detectable concentration was $44 \mathrm{fmol} / \mathrm{ml}$. The intra- and interassay coefficients of variation were 5.9 and $14.2 \%$ for a $446 \mathrm{fmol} / \mathrm{ml}$ standard. The antiserum showed approximately $5 \%$ cross-reactivity with bombesin but no detectable reactivity with substance $P$ or related tachykinins. Serial dilution of the immunoreactivity in extracts of rat stomach and small intestine resulted in lines whose slopes were parallel to the GRP standard (Peninsula Laboratories, Belmont, CA, USA). Analysis of extracts of rat gastrointestinal tissues by gel filtration showed the GRP-like immunoreactivity was heterogeneous. A component with the same elution volume as porcine GRP and a smaller component that may represent neuromedin C (residues 18-27 of GRP) were detected.

\section{Statistical analysis}

All values are given as mean \pm SD. Comparison between groups are made using Wilcoxon's rank sum test for unpaired data and significant differences were confirmed using Student's test for unpaired data. Confidence limits were set at $p<0.05$ or $p<0.01$.

\section{Results}

As shown in Table 1, the tumour-bearing rats had become, by 14 days, hyperphagic, markedly hyperinsulinaemic and severely hypoglycaemic. Hyperphagia appeared with the onset of hypoglycaemia by day 3 of the study. The diurnal changes in food intake observed in control rats was abolished in the insulinoma rats, apart from a small decrease between 05.00 and 11.00 hours. The rate of growth of the transplanted insulinoma tumour was extremely rapid $(0.8 \pm 0.3 \mathrm{~g} /$ day) (Table 2$)$. This rate is considerably greater than that observed by Chick et al. [1] in the original stock, suggesting that the sequence of serial transplantations that has led to the University of Surrey tumour subline has resulted in selection of cells with a greater mitotic rate. After 14 days 
Table 4. The effects of a transplantable insulinoma upon concentrations of regulatory peptides in the rat gastrointestinal tract

\begin{tabular}{|c|c|c|c|c|c|c|c|c|}
\hline & \multicolumn{4}{|l|}{ Stomach } & \multicolumn{4}{|c|}{ Small intestine } \\
\hline & \multicolumn{2}{|l|}{ pmol/organ } & \multicolumn{2}{|l|}{$\mathrm{pmol} / \mathrm{g}$} & \multicolumn{2}{|l|}{ pmol/organ } & \multicolumn{2}{|l|}{$\mathrm{pmol} / \mathrm{g}$} \\
\hline & Insulinoma & Control & Insulinoma & Control & Insulinoma & Control & Insulinoma & Control \\
\hline Somatostatin & $267 \pm 90$ & $228 \pm 89$ & $193 \pm 70$ & $184 \pm 73$ & $364 \pm 62$ & $307 \pm 46$ & $40 \pm 7$ & $51 \pm 11$ \\
\hline VIP & $61 \pm 9$ & $56 \pm 11$ & $44 \pm 6$ & $45 \pm 9$ & $630 \pm 81^{b}$ & $449 \pm 113$ & $69 \pm 10$ & $74 \pm 22$ \\
\hline N-GLI & - & - & - & - & $1197 \pm 153^{\mathrm{b}}$ & $544 \pm 164$ & $131 \pm 16^{b}$ & $89 \pm 29$ \\
\hline Substance P & $27 \pm 4$ & $25 \pm 5$ & $20 \pm 3$ & $20 \pm 4$ & $243 \pm 49^{a}$ & $178 \pm 22$ & $27 \pm 5$ & $30 \pm 6$ \\
\hline Neurokinin A & $24 \pm 5$ & $31 \pm 9$ & $17 \pm 4^{a}$ & $25 \pm 6$ & $208 \pm 81$ & $184 \pm 53$ & $23 \pm 9$ & $33 \pm 10$ \\
\hline $\begin{array}{l}\text { Gastrin-releasing } \\
\text { peptide }\end{array}$ & $42 \pm 17^{b}$ & $89 \pm 17$ & $31 \pm 13^{b}$ & $72 \pm 15$ & $117 \pm 16$ & $94 \pm 15$ & $13 \pm 2$ & $16 \pm 3$ \\
\hline
\end{tabular}

Results expressed as mean $\pm \mathrm{SD}(n=8) .{ }^{\mathrm{a}} p<0.05 ;{ }^{\mathrm{b}} p<0.01$ versus control. Gastric tissue contained $<1 \mathrm{pmol} / \mathrm{g}$ C-GLI and N-GLI

the body weights of the animals in the two groups were not different, but the weight of the small intestine of the tumour-bearing rats had increased by $49 \%(p<0.01)$. Differences in the weights of the stomachs were not significant.

\section{Regulatory peptides in tumour extracts}

In addition to the very high concentration of insulin, comparable to the levels reported by other workers [5, 10], extracts of all the tumours contained appreciable quantities of SPLI and GRP-LI (Table 3). Concentrations of VIP, neurokinin A, somatostatin and glucagon were lower except for one tumour which contained $7.6 \mathrm{pmol} / \mathrm{g}$ of GLI.

\section{Regulatory peptides in gastrointestinal tissues}

Changes in the concentration ( $\mathrm{pmol} / \mathrm{g}$ ) and total content (pmol/organ) of regulatory peptides in the gastrointestinal tract during tumour growth are shown in Table 4. No significant changes in the concentration or content of somatostatin, substance $\mathbf{P}$ and VIP in the stomach were observed. A decrease $(32 \% ; p<0.05)$ in the concentration of neurokinin A was seen. However, in view of the increased weight of the stomach of some of the insulinoma-bearing rats, differences in the total content of gastric NKA-LI were not significant. The most striking effect of tumour growth upon gastric regulatory peptides was the decrease in concentration $(57 \%$; $p<0.01)$ and content $(53 \% ; p<0.01)$ of gastrin-releasing peptide.

No significant changes in either concentration or content of somatostatin, GRP and neurokinin A in extracts of small intestine were observed. Although the concentrations of substance $P$ and VIP in the intestines of the insulinoma-bearing rats were not different from control rats, the appreciably greater weights of the intestines resulted in a significant increase in total content of
VIP $(40 \% ; p<0.01)$ and substance P $(37 \% ; p<0.05)$. Both the concentration $(47 \% ; p<0.01)$ and the total content $(120 \% ; p<0.01)$ of glucagon-like immunoreactivity measured with an $\mathrm{N}$-terminally directed antibody (enteroglucagon) were increased in the insulinomabearing rats. The slight rise in C-GLI content in the intestines of the insulinoma rats probably reflects the small degree of cross-reactivity of enteroglucagon with antiserum $30 \mathrm{~K}$ and the contribution of immunoreactive proteolytic fragments of enterglucagon.

\section{Discussion}

The changes in the gastrointestinal tract of NEDH rats in response to insulinoma growth demonstrated in the present study may be compared with changes occurring during streptozotocin-induced diabetes [11] and during malabsorption following pancreatic acinar atrophy [12]. Hyperphagia and a significant increase in weight of the small intestine were observed in all three studies. In view of the shorter duration of the present study, the rate of increase of intestinal weight in the insulinoma rats $(0.22 \mathrm{~g} /$ day $)$ was greater than in diabetic rats $(0.06 \mathrm{~g} /$ day $)$ and rats with acinar atrophy $(0.02 \mathrm{~g} /$ day $)$. The comparison indicates, however, that the observed increase in gut weight in this study is more likely to be a consequence of increased food intake than a trophic effect of high circulating insulin. The lack of increase in body weight despite hyperphagia and hyperinsulinaemia in the tumour rats contrasts with the dynamic phase of increasing obesity, which occurs within $24 \mathrm{~h}$, in hyperphagic rats with ventromedial hypothalamic lesions [17]. In both cases, the animals take food at abnormal times during the 24-h cycle. Rapid gastric emptying rather than hypersecretion of insulin has been proposed as the primary cause of hyperphagia in the lesioned animals [18]. The failure of the insulinoma rats to gain weight probably reflects the strong influence of malignant disease in these animals. 
The possibility that other factors trophic to the small intestine are released by the tumour and contribute to its growth deserves consideration. All tumour extracts contained substance $P$ and gastrin-releasing peptide. GRP stimulates cell division and DNA synthesis in cell lines derived from small cell lung carcinomas [19] and in Swiss 3T3 fibroblasts [20]. Similarly, both substance P and neurokinin A stimulate DNA synthesis in cultured arterial smooth muscle cells and human skin fibroblasts [21]. The extremely rapid rate of clearance of the peptides in the circulation, however, would render improbable a role for these substances as endocrine growth factors but the possibility that they are acting as autocrine tumour growth factors deserves further study. Substance $\mathrm{P}$ and neurokinin $\mathrm{A}$ are the products of a single gene that generates two mRNAs in a tissue-specific manner by alternative RNA splicing [22]. One mRNA encodes $\beta$-preprotachykinin, which generates both substance $\mathrm{P}$ and neurokinin $\mathrm{A}$. A second mRNA encodes $\alpha$-preprotachykinin, which generates substance $\mathrm{P}$ only. The concentrations of SPLI in the tumour extracts were between 2 and 15 times higher than the concentrations of NKA-LI, suggesting that the tumour may be preferentially producing $\alpha$-preprotachykinin mRNA. Production of GRP and SPLI may be a property of the particular tumour sub-line investigated, as extracts of a different, more slowly growing sub-line contained only trace amounts of these peptides.

GRP is found in nerves in all layers of the stomach wall; in the rat fed ad libitum it is a powerful stimulus for the release of gastrin [23]. Stimulation of the vagus nerves results in a marked increase in both antral and fundic GRP release [24], and so the depletion in gastric GRP content in the tumour-bearing rats may be a consequence of hypersecretion mediated through excitation of the vagus by insulin-induced hypoglycaemia. The plasma concentrations of GRP in rats, however, are below the detection limit of the radioimmunoassay. Alternatively, the increase in gastric activity associated with the hyperphagia may exercise a gastrin mediated negative feedback effect upon the synthesis of GRP. In the fed rat, GRP also stimulates insulin release [23] so that a feedback inhibition of GRP synthesis in the stomach by insulin is a possibility. The fact that GRP concentrations in the intestine do not change suggests that insulin does not exercise a similar feedback inhibitory effect on the synthesis of GRP in the gut.

The increases in both concentration (47\%) and total content (120\%) of GLI (enteroglucagon) in the insulinoma-bearing rats were more pronounced than in the rats with streptozotocin-diabetes [11] and with acinar atrophy [12]. GLI measurements were performed in the streptozotocin-induced diabetes study but not reported [11]. Changes in the concentration of GLI in the small intestine of the diabetic rats were not significant, but total content of GLI in the diabetic rats was significantly higher $(p<0.05)$ than in control animals. Similarly, the total content of GLI, but not the concentration, was slightly increased in rats with experimental pancreatic atrophy. The physiological role of GLI is unclear. Situations in which there is an increased turnover of enterocytes, e.g. tropical sprue, coeliac disease and during mucosal overgrowth following partial intestinal resection and jejunal-ileal bypass, are associated with an increase in the concentration of gut GLI [25]. These observations have led to the proposal [25] that GLI represents a factor that promotes mucosal growth within the small intestine. The present findings are consistent with this hypothesis, but leave open the question whether the GLI increase is a cause of the increase in gut weight or a consequence of the increase in food intake with resulting mucosal stimulation by malabsorbed nutrients.

In mammals, substance P, VIP and GRP are localized to the non-epithelial layer of the bowel and have been demonstrated exclusively in nerves [26]. Somatostatin has a dual location in mucosal D cells and in nerves of the ganglionated plexuses. The increase in VIP content of the intestines of insulinoma-bearing rats was also observed in rats with streptozotocin-induced diabetes [11], suggesting that the increase may represent a non-specific effect of hyperphagia. However, the increase in gastric somatostatin content and the decrease in gastric and intestinal substance $P$ content in the diabetic rats was not seen in the present study, suggesting that those changes may be more specifically related to the diabetic state.

Acknowledgements. The work was supported by the Stiftung Volkswagenwerk and the Cancer Research Campaign, UK (SP 1630). Antiserum $30 \mathrm{~K}$ was a gift from Professor R.H. Unger, Southwestern Medical School, Dallas, TX, USA, and antiserum to VIP was kindly supplied by Dr. A. Schafmayer, Department of Surgery, University of Göttingen, FRG.

\section{References}

1. Chick WL, Warren S, Chute RN, Like AA, Lauris V, Kitchen KG (1977) A transplantable insulinoma in the rat. Proc Natl Acad Sci USA 74: 628-632

2. Flatt PR, Tan K, Bailey CJ, Swanston-Flatt SK, Marks V, Webster JD (1982) Plasma glucose and insulin concentrations after implantation and surgical resection of transplantable rat insulinoma. Biochem Soc Trans 10: 273-274

3. Masiello P, Wollheim CB, Janjic D, Gjinovci A, Blonda IB, Praz GA, Renold AE (1982) Stimulation of insulin release by glucose in a transplantable rat islet cell tumour. Endocrinology 111: 2091-2096

4. Sopwith AM, Hutton JC, Naber SP, Chick WL, Hales CN (1981) Insulin secretion by a transplantable rat islet cell tumour. Diabetologia 21: 224-229

5. Gold G, Gishizky ML, Chick WL, Grodsky GM (1984) Contrasting patterns of insulin biosynthesis, compartmental storage and secretion. Rat tumor versus islet cells. Diabetes 33: 556-561

6. Bhathena SJ, Timmers KI, Oie HK, Voyles NR, Recant L (1985) Cytosolic insulin degrading activity in islet-derived tumor cell lines and in normal rat islets. Diabetes 34: 121-128

7. Hutton JC, Penn EJ, Peshavaria M (1982) Isolation and characterization of insulin secretory granules from a rat islet cell tumor. Diabetologia $23: 365-373$ 
8. Eisenbarth GS, Oie H, Gazdar A, Chick W, Schultz JA, Scearce RM (1981) Production of monoclonal antibodies reacting with rat islet cell membrane antigens. Diabetes 30: 226-230

9. Rakieten N, Gordon BS, Beaty A, Cooney DA, Davis RD, Schein PS (1971) Pancreatic islet cell tumors produced by the combined action of streptozotocin and nicotinamide. Proc Soc Exp Biol Med 137: 280-283

10. O'Hare MMT, Shaw C, Swanston-Flatt SK, Marcelli M, Buchanan KD, Flatt PR (1985) Influence of a transplantable insulinoma on the pancreatic status of insulin and pancreatic polypeptide in the rat. Diabetologia 28: 157-160

11. Ballmann M, Conlon JM (1985) Changes in the somatostatin, substance $P$ and vasoactive intestinal polypeptide content of the gastrointestinal tract following streptozotocin-induced diabetes in the rat. Diabetologia 28: 355-358

12. Ballmann M, Fölsch UR, Conlon JM (1985) The effect of pancreatic acinar atrophy upon the concentration of vasoactive intestinal polypeptide, substance $P$, somatostatin and glucagon in the pancreas and gastrointestinal tract of the rat. Digestion 32:70-75

13. Kenny AJ (1955) Extractable glucagon of the human pancreas. $J$ Clin Endocrinol Metab 15: 1089-1105

14. Melani E, Ditschumeit H, Bartelt KM, Friedrich H, Pfeiffer EF (1965) Über die radio-immunologische Bestimmung von Insulin im Blut. Klin Wochenschr 43: 1000-1007

15. Conlon JM, Deacon CF, Richter G, Schmidt WE, Stöckmann F, Creutzfeldt W (1985) Measurement and partial characterization of the multiple forms of neurokinin A-like immunoreactivity in carcinoid tumours. Regul Pept 13: 183-196

16. Conlon JM, Hansen HF, Schwartz TW (1985) Primary structure of glucagon and a partial sequence of oxyntomodulin (glucagon-37) from the guinea pig. Regul Pept 11:309-320

17. Rabin BM (1972) Ventromedial hypothalamic control of food intake and satiety: A reappraisal. Brain Res 43: 317-342

18. Duggan JP, Booth DA (1986) Obesity, overeating and rapid gastric emptying in rats with ventromedial hypothalamic lesions. Science 231: 609-611
19. Weber S, Zuckerman JE, Bostwick DG, Bensch KG, Sikic BI, Raffin TA (1985) Gastrin releasing peptide is a selective mitogen for small cell lung carcinoma in vitro. J Clin Invest 75: 306-309

20. Rozengurt E, Sinnett-Smith J (1983) Bombesin stimulation of DNA synthesis and cell division in cultures of Swiss 3T3 cells. Proc Natl Acad Sci USA 80: 2936-2940

21. Nilsson J, von Euler AM, Dalsgaard C-J (1985) Stimulation of connective tissue cell growth by substance $P$ and substance $K$. Nature 315: 61-63

22. Nawa H, Kotani H, Nakanishi S (1984) Tissue specific generation of two preprotachykinin mRNAs from one gene by alternative RNA splicing. Nature 312: 729-734

23. Greeley GH, Thompson JC (1984) Insulinotropic and gastrinreleasing action of gastrin-releasing peptide (GRP). Regul Pept 8 : $97-103$

24. Knuhtsen S, Holst JJ, Knigge U, Olsen M, Nielsen OV (1984) Radioimmunoassay, pharmacokinetics and neuronal release of gastrin-releasing peptide in anaesthetized pigs. Gastroenterology 87: 372-378

25. Bloom SR, Polak JM (1982) Trophic influences in the gut In: Bloom SR, Polak JM, Lindenlaub E (eds) Systemic role of regulatory peptides. Schattauer, Stuttgart New York, pp 221-227

26. Ferri G-L, Adrian TE, Ghatei MA, O'Shaughnessy DJ, Probert L, Lee YC, Buchan AM, Polak JM, Bloom SR (1983) Tissue localization and relative distribution of regulatory peptides in separated layers from the human bowel. Gastroenterology 84: 777-786

Received: 11 December 1985

and in revised form: 21 February 1986

Dr. J. M.Conlon

Klinische Arbeitsgruppe der MPG

Goßlerstraße 10D

D-3400 Göttingen

FRG 